\title{
TOWARDS ACHIEVING FOOD SECURITY IN NIGERIA: A FUZZY COMPREHENSIVE ASSESSMENT OF HEAVY METALS CONTAMINATION IN ORGANIC FERTILIZERS
}

(D) Hammed Adeniyi
Salami $^{1+}$
(D) Saheed
Matemilola $^{2}$
(D) Sulaiman Akorede
Fasasi $^{3}$
(iD) Musa Opeyemi
Ahmed
(i) Ismail Adebayo
Adigun $^{5}$
(D) Akeem Adelabu
Adeleke $^{6}$
(D) Segun Michael
Fashina $^{7}$
(i) Oluwashina
Olowosokedile $^{8}$

Article History

Received: 23 August 2021 Revised: 27 September 2021 Accepted: 18 October 2021 Published: 9 November 2021

\section{Keywords}

Food security Organic fertilizers

Heavy metal contamination Fuzzy comprehensive assessment Membership function. Nutrient quality.

\author{
${ }_{1,3,4,7,8}$ Department of Agricultural and Environmental Engineering, University \\ of Ibadan, Nigeria. \\ 'Email: salamihammed6@gmail.com Tel:+2348068638718 \\ ${ }^{s}$ Email: akoredefasasi@gmail.com Tel: +2348102954219 \\ ${ }^{4}$ Email: kalamu979@gmail.com Tel: +2348134558079 \\ 'Email: segunfashina@yahoo.com Tel: +2348102157638 \\ ${ }^{8}$ Email: sukanmi14@gmail.com Tel: +2348035483951 \\ ${ }^{2}$ Department of Public Law with Reference to the Law of Environment and \\ Planning, Brandenburg University of Technology, Cottbus-Senftenberg, \\ Cottbus, Germany. \\ ${ }^{2}$ Email: matem7_saheed@yahoo.com Tel: +2348119972923 \\ ${ }^{5}$ Department of Agricultural and Environmental Engineering, University of \\ Ibadan, Nigeria; Department of Agricultural and Bio-Environmental \\ Engineering, Osun State Polytechnic, Nigeria. \\ ${ }^{5}$ Email:adigunadebayo66@gmail.com Tel:+2347068568122 \\ ${ }^{6}$ Department of Agricultural and Bio-Environmental Engineering, Osun \\ State Polytechnic, Nigeria. \\ ${ }^{6}$ Email: akeemadelabu2017@gmail.com Tel: +2348032482244.
}

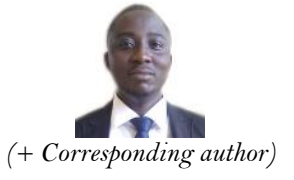

ABSTRACT

In the quest towards achieving the Zero hunger agenda of the sustainable development goals by 2030, the utilization of organic fertilizers, for soil amendment purposes, has been posited as a feasible alternative for overcoming the negative impacts of inorganic fertilizers. Despite its manifold benefits, the use of untreated and improperly treated organic materials in agricultural production is however capable of introducing toxic metals in the soil-plant systems causing health and agro-environmental impacts. In this study, available organic fertilizers use by Nigerian farmers were selected and analyzed for nutrient values and most importantly, heavy metal contamination. The degree of contamination in each sample was modeled using fuzzy comprehensive assessment. The manure samples possessed optimum nutritional values; the nitrogen, phosphate, and potash contents ranged from $0.91-7.44,0.06-1.61,0.14-0.58 \%$ respectively. The fuzzy algorithm results categorized all the organic fertilizers as pristine, with a membership degree ranging from 35 to $99 \%$. However, an excessive level of toxic contamination, with a membership function between 3 to $33 \%$ was observed. The major contaminants were identified as $\mathrm{Zn}, \mathrm{Cr}$, and $\mathrm{Cd}$ with an individual contribution of 16 , 29 , and 33\% respectively. Adequate remediation techniques and good management practices that reduce the concentration of heavy metals in the organic fertilizers especially that of $\mathrm{Zn}, \mathrm{Cr}$, and $\mathrm{Cd}$, should therefore be promoted among the producers and users of these soil improvers in Nigeria.

Contribution/Originality: This study adopted fuzzy comprehensive assessment to model the degree of heavymetal contamination in organic fertilizers that are available to subsistence farmers in Nigeria. The model ranked $\mathrm{Cd}, \mathrm{Cr}$, and $\mathrm{Zn}$ as the pollutants with the highest contribution to the high level of heavy-metal contamination in the studied organic fertilizers. 


\section{INTRODUCTION}

Food is the source of many types of macro and micronutrients that deliver the energy that the body needs to function properly. Inadequate or lack of access to food can therefore affect human health in several ways [1]. Arguably, not much progress has been made in the effort to reduce global food insecurity in the last decade. FAO in the 2019 edition of The State of Food Security and Nutrition in the World reported that as of 2005 about 947.2 million people in the world lack adequate access to food to meet their nutritional needs. The number of undernourished persons dropped to 785.4 million in 2015 but again gradually rose to 821.6 million people in 2018 . In Africa, the figure consistently rose from 196 million in 2005 to 256.1 million undernourished persons in 2018 [2]. With this dire figure of undernourished people in Africa in mind, extreme poverty cannot be the factor to blame since even resource-rich countries in the region also experience a high prevalence of undernourishment [3]. Thus, the United Nations (UN) when setting the ambitious targets of 2030 for the Zero hunger agenda of the Sustainable Development Goals (SDGs) recognized that beyond the eradication of hunger, "access by all people ... to safe, nutritious and sufficient food ..." is a key for food security to take place [4].

One of the important factors that affect the safety and nutritional value of food is the use of agricultural chemicals such as fertilizers and pesticides in their production or/and processing [5]. It is a lifelong agricultural tenet that healthy soils produce nutritious food, which results in healthy living for humans and animals. In the early part of the $20^{\text {th }}$ century, food nutritional values and the nexus to agricultural practices were widely discussed. However, after the Second World War, interest in soil and nutritional quality waned due to the widespread use of chemical fertilizers, pesticides, and food additives that lead to increased availability and variety of basic food crops. Instead, postharvest handling and storage of food crops are being emphasized [6]. In fact, the USDA report of 1980 recommended and concluded that there was no sufficient scientific evidence to prove that chemical fertilizers-based produce is inferior to organically grown produce in terms of nutritional quality [5]. However, many recent studies such as Jallow, et al. [7]; Prashar and Shah [8] and Nicolopoulou-Stamati, et al. [9] have shown that chemical or inorganic fertilizers and pesticides significantly exacerbate the challenge of air, water, and soil pollution as well as causing health complications in human amongst other problems. Thus, the use of organic fertilizers which are mostly derived from substances that range from fresh to dried plant materials to animal manure and municipal wastes [10] have gained popularity in recent years even though the history dates back to several thousand years ago [11].

Sustainable agricultural practices have become a major global topic, and this highlights the leverage which organic fertilizer rides on in respect of its potential benefits [12]. Both organic and inorganic fertilizers are composed of different ingredients that deliver essential nutrients to plants in different ways, especially nitrogen (N), phosphorus $(\mathrm{P})$, and potassium $(\mathrm{K})$ as well as other macro and microelements (Ca, $\mathrm{Mg}, \mathrm{S}, \mathrm{Fe}, \mathrm{B}, \mathrm{Mn}, \mathrm{Zn}, \mathrm{Mo}, \mathrm{Cu}$ ). While organic fertilizer attempts to create a healthy condition for plant growth in the long term, inorganic fertilizer delivers rapid nutrition which adds less value to the soil in the long term [13]. Though organic fertilizers are generally and significantly more expensive than inorganic fertilizers, the excess cost is usually over-indemnified by the benefit it brings. Organic fertilizers continue to improve the nutrient quality of the soil even long after the plant has taken its required nutrients. So, the more organic fertilizer is fed to the soil, the better the nutritional composition and texture [14]. Also, although inorganic fertilizer delivers nutrients almost immediately to the plants, it is often exposed to leaching when rain or irrigation water washes the fertilizers below the roots of the plant while the excessive application can increase the concentration of toxic salt in the soil causing nutrient imbalances. Organic fertilizers can build up the concentration of nutrients in the soil but increasing soil toxicity is not common since they are made from organic substances that enable them to fully decompose [13, 14]. Furthermore, because they are sourced from organic materials with limited processing, organic fertilizers require only a limited amount of fossil fuel for their production. Thus, atmospheric emissions from the production of organic fertilizers are significantly less compared to that of inorganic fertilizers [12]. 
Despite the manifold benefits, food quality and safety are continuously threatened due to the utilization of untreated and improperly treated organic materials in agricultural production [15]. Through the repeated application of fertilizers (organic and inorganic), heavy metals can accumulate in soil with potential negative consequences on soil quality [16]. Soil contamination through point and non-point sources is known to adversely affect soil biota through soil-microbe interactions and microbial processes; which in turn have negative impacts on large and small mammals, invertebrates, and beneficial soil insects [17]. Cultivation of crops on contaminated farmland, due to the usage of fertilizers from animal wastes and some other organic materials, may lead to the bioaccumulation of heavy metals and pathogens into crop during the plant growing stage; which can negatively affect the plant's biochemical, metabolic and physiological characteristics [18]. Food contamination generally occurs by translocation and root uptake from the soil, as well as by leaf absorption from polluted air [19]. The bioaccumulation of toxic pollutants in plant tissue is greatly influenced by factors such as plant species and types, soil $\mathrm{pH}$ and redox potential, soil organic matter content as well as the existing concentration of heavy metals in soil [18]. Long-term exposure of humans to toxic metals, through the ingestion of contaminated food, can greatly deteriorate human health and increase the risk of carcinogenic and non-carcinogenic cells [20].

Furthermore, the use of organic manure and composts are capable of causing agro-environmental problems. Organic fertilizers contain materials that are rich in Nitrogen $(\mathrm{N})$ and high extractable nutrients like $\mathrm{P}, \mathrm{K}, \mathrm{Ca}, \mathrm{Mg}$, $\mathrm{Cu}$ and $\mathrm{Zn}$ to improve soil fertility [13]. Nonetheless, the continued use of organic fertilizer could cause accumulation of some nutrients and eventually loss of excess nutrients to the environment through erosion to close by low land and water-bodies causing eutrophication [21]. When nutrients from fertilized farm runoff into water bodies, they stimulate the growth and reproduction of algae (algal bloom) which depletes the amount of dissolved oxygen in the water causing suffocation of aquatic lives and degraded water quality. Additionally, these algae have the potential to be toxic as blue-green algae (cyanobacteria) have been documented to be capable of causing rashes, nausea, and respiratory problems for humans. It can also result in death for animals that drink from affected water. Water bodies that are contaminated by ammonia from runoffs from fresh manure application farmlands are also toxic to aquatic species. Ammonia concentration in water even as low as 0.02 parts per million (ppm) can be lethal for aquatic lives [22]. Nitric oxide $\left(\mathrm{N}_{2} \mathrm{O}\right)$ and ammonia from manure and mineral fertilizers also cause soil acidification. Fertilization is in fact responsible for over $70 \%$ of anthropogenic $\mathrm{N}_{2} \mathrm{O}$ emissions which represents one of the most important factors for the depletion of the ozone layer, thereby contributing to global warming [21].

Therefore, even though many positives can be drawn from the use of organic fertilization especially in respect of sustainable agriculture, measures must be put in place to mitigate its attendant negative impacts, especially as it relates to heavy metal contamination. To establish these measures, several research works have been carried out in which the concentrations of heavy metals contamination in organic fertilizers were reported and compared with existing standards; high concentrations of heavy metals, beyond established standards, in farmyard manure, sewage, treated and untreated wastewater have been comprehensively discussed [18]. The characterization of heavy metals in five different livestock manures (poultry, ostrich, sheep, goat, and cattle) was carried out by Irshad, et al. [23] findings revealed the highest concentrations of trace metals in poultry manure while goat manure has the least concentration of heavy metals. Chibueze, et al. [24] evaluated the heavy metals concentrations in farmyard manure and chemical fertilizers used in Southeastern Nigeria, a high prevalence of Iron ( $\mathrm{Fe})$ concentration in pig manure was observed as compared with synthetic fertilizers. Similarly, Gong, et al. [20] assessed the concentrations of trace metals in 117 animal-based manures; it was observed that the concentrations of Chromium (Cr), Cadmium $(\mathrm{Cd})$, Lead $(\mathrm{Pb})$, and Arsenic (As) all exceeded the Chinese organic fertilizers standards limits in the range of $0.85-$ $5.98 \%$ while the concentrations of Nickel $(\mathrm{Ni})$, Copper $(\mathrm{Cu})$ and Zinc $(\mathrm{Zn})$ exceeded the limits set by the German authority in the range of $1.17-35.04 \%$.

Unarguably, and to the best of the authors' knowledge, it is obvious that the majority of the researches on the impact assessment of heavy metals contamination in organic fertilizers focused more on the conventional method of 
reporting and comparing pollutants' concentrations with known standards. This approach promotes vagueness and inconsistency in data quality and as such prevents the establishment of the combined environmental impact of the contaminants, suitable for impact rating and comparative assessment, as well as the evaluation of the individual contribution of these pollutants [25]. There is therefore the need to adopt novel and advanced methodologies to ascertain these impacts and solves the aforementioned deficiencies of the conventional method; this can be achieved using suitable approaches such as fuzzy comprehensive assessment (FCA). FCA is a mathematical tool that has gained widespread applications in environmental modeling; it entails the utilization of predetermined weights to comprehensively evaluate the contribution of various pollutants and reduces fuzziness through the utilization of membership functions [26]. With the strategic importance of organic fertilization in the quest towards achieving food security in Nigeria as well as meeting the 2030 zero hunger agenda of SDGs, this study thus adopts the principle of FCA to ascertain and rank the cumulative impact of heavy metals contamination in the major organic fertilizers adopted by farmers in Nigeria.

\section{MATERIALS AND METHODS}

\subsection{Sampling and Material Handling}

To increase agricultural productivity, peasant farmers in Nigeria and other Africa countries rely often on the use of organic materials as soil improvers without adequately following the strict guidelines stipulated for the use of these wastes in agriculture; at present, the common organic materials use in Nigeria are compost, cow dung, sheep dung, pig and poultry manures, groundnut cake, Neem cake, human excreta, urine, sewage sludge and unused materials from abattoir $[18,27,28]$. Table 1 presents the information on the organic fertilizers that were considered for this study. The selection was based on a preliminary survey; these organic fertilizers were subsequently grouped into animal-based, plant-based, composite, and sludge-based. The different types of organic fertilizers were collected from designated sources using sample containers that have been prewashed with detergent and deionized water. To meet the standard of Class A biosolid, as it relates to pathogen and vector attraction reduction requirements, the collected samples were heat-dried according to the procedure specified by USEPA [29]. Prior to chemical analysis and to ensure homogeneity, the samples were air-dried, crushed, passed through a $2 \mathrm{~mm}$ sieve, and stored in new clean sample containers [23].

Table-1. Description of the assessed organic fertilizers.

\begin{tabular}{l|l|l}
\hline Category & Designation & Remarks \\
\hline Animal-based fertilizer & & \\
\hline Cattle (beef) manure & CAM & Cow dung \\
\hline Poultry manure & POM & Poultry litter (sawdust) plus excreta \\
\hline Sheep manure & SHM & Sheep excreta \\
\hline Plant-based fertilizer & GNC & $\begin{array}{l}\text { The residual obtained after groundnut oil has been extracted } \\
\text { from peanuts. }\end{array}$ \\
\hline Groundnut cake & NMC & $\begin{array}{l}\text { Neem seeds were obtained, sun-dried for 20 days, and crushed } \\
\text { to produce the cake. }\end{array}$ \\
\hline Neem cake & PCM & $\begin{array}{l}\text { A partially composted organic material was collected from } \\
\text { Jams Organic Farms and Kitchens, Oyo State, Nigeria. It is a } \\
\text { mixture of Poultry manure (66.67\%), cashew leaves } \\
\text { Neem leaves (0.33\%), and Sawdust (25\%) sourced from a } \\
\text { commercial sawmill. }\end{array}$ \\
\hline Pseudo-compost & & $\begin{array}{l}\text { Rumen digest plus blood, collected (and dried) from Akinyele } \\
\text { abattoir in Ibadan, Oyo State, Nigeria. }\end{array}$ \\
\hline Sludge-based fertilizer & AWS
\end{tabular}


2.2. Chemical Analysis

\subsubsection{Analysis of Samples for Total Nitrogen Content}

The total nitrogen (TN) content was determined using the micro Kjeldahl method; which is characterized by the following key steps: Kjeldahl digestion, distillation, and titration of NH3-N [30]. Two grams of each organic fertilizer were measured and mixed with sulphuric acid and Kjeldahl tablet catalyst (Merck, South Africa) in a Kjeldahl flask; the resulting mixture was digested at $400^{\circ} \mathrm{C}$ for at least 30 minutes until a clear solution is formed [31]. The flask was removed from the heater, cool down to room temperature, and then transferred into a distillation unit in admixture with $50 \mathrm{ml}$ of water. The distillation was done in about $30-40$ minutes [31]. A boric acid solution containing methyl red and bromocrescyl green indicator (Merck, South Africa) was used as the absorbing solution to capture the dissolved ammonia gas. Afterward, Sodium hydroxide was used to neutralize the reaction process and the resulting greenish boric acid solution was then titrated against $0.1 \mathrm{M} H \mathrm{HCl}$ until a permanent light pink color appeared. Finally, the percentage total nitrogen was calculated using the titer values for all the treatments in Equation 1 [32].

$$
\% T N=\frac{(\mathrm{ml} \text { standard acid }-\mathrm{ml} \text { blank }) \text { x Normality of acid } \mathrm{x} 1.4007}{\text { weight of sample in grams }}
$$

\subsubsection{Analysis of Samples for Total Phosphate Content}

The widely accepted gravimetric quinolinium phosphomolybdate methodology was adopted for the determination of the percentage total phosphate (TPH) [33]. This method is simple, possesses acceptable accuracy, and enhances minimal ions interference [34]. One gram of individual sample was mixed with magnesium nitrate solution in an evaporation dish. Heat treatment was introduced to destroy the constituent organic matter and thereafter dissolved in $10 \mathrm{ml} \mathrm{HCl}$. The resulting mixture was cooled to room temperature, diluted to $250 \mathrm{ml}$, and then reacted with a quimociac reagent in a boiling medium. The corresponding orthophosphate precipitates as quinolinium phosphomolybdate, which was then weighed gravimetrically [31]. The exact percentage of total phosphate can be determined using Equation 2 [34].

$$
\% T P H=\frac{3.207 \times(A-B)}{W} \times d o f
$$

Where: A is the weight of sample precipitate (in grams), B is the weight of sample precipitate (in grams), dof is the degree of freedom while $\mathrm{W}$ is the weight of sample taken (in grams).

\subsubsection{Analysis of Samples for Heary Metal Concentration}

Using reagent grade chemicals, the concentrations of $\mathrm{K}, \mathrm{Cd}, \mathrm{Cu}, \mathrm{Pb}, \mathrm{Ni}, \mathrm{Zn}, \mathrm{Cr}, \mathrm{Fe}, \mathrm{As}$, Selenium (Se), Aluminum (Al), Manganese (Mn), Barium (Ba), Cobalt (Co), Silver (Ag) and Vanadium (V) in the samples were analyzed by using the principle of microwave atomic emission spectrometry (MP-AES). The numerous benefits and the suitability of MP-AES for metal analysis have been rigorously reviewed by Balaram [35]. According to Gong, et al. [20] the chemical analysis of standard samples, duplicate samples, and method blanks was equally carried out to ensure quality control and assurance. Prior to chemical analysis, 1 gram (dry weight) of each sample, in admixture with $4 \mathrm{ml}$ of $50 \%$ nitric acid $\left(\mathrm{HNO}_{3}\right)$ and $10 \mathrm{ml}$ of $20 \% \mathrm{Hydrochloric}$ acid $(\mathrm{HCl})$, was prepared. Following the SW-846 method 3050B established by the United States Environmental Protection Agency (USEPA), digestion of the mixture was carried out on a hotplate in a fume hood with a temperature not exceeding $90^{\circ} \mathrm{C}$ for about an hour. The final volume of the digest was approximately $5 \mathrm{ml}$ for each sample. The digest was then filtered and diluted to $50 \mathrm{ml}$ using ultra-pure deionized water. After the MP-AES analysis, data output in part per million (ppm 
or $\mathrm{mg} / \mathrm{L}$ ) was converted to $\mathrm{mg} / \mathrm{kg}$ using Equation 3 [36]. For $\mathrm{K}$, its concentration, in $\mathrm{mg} / \mathrm{kg}$, was first converted to a percentage and then to percentage total potash (TPO) by multiplying the percentage K content with 1.2 [37].

$$
\text { Conc. }\left(\frac{\mathrm{mg}}{\mathrm{kg}}\right)=\frac{\text { Conc. }(\mathrm{mg} / \mathrm{L}) \times \text { Final Volume }(\mathrm{L}) \mathrm{x} \text { Dilution Factor }}{\text { Weight of sample }(\mathrm{kg})}
$$

\subsection{Modelling of Pollution Impact}

The pollution impact of the regulated contaminants - As, Cd, Se, $\mathrm{Pb}, \mathrm{Ni}, \mathrm{Cr}, \mathrm{Cu}$, and $\mathrm{Zn}$ - in the chosen organic fertilizers was modeled using FCA. This approach is suitable for extracting transparent, systemic, reliable, and logical information from vague or uncertain data; and it involves the adoption of fuzzy reasoning techniques to create a membership function matrix that is subsequently subjected to a weighted average assessment [25, 38]. According to Akintola, et al. [26] and Adebowale, et al. [39] the stepwise procedure for utilizing FCA principles is detailed as follows:

Step 1: Establishment of assessment parameters and limits

This entails the identification and adoption of suitable environmental parameters that effectively represent the system to be studied as well as selecting the range of criteria limits for the respective parameters based on relevant regulatory standards Table 2 . Equations 4 and 5 depict the set of functions that defined these variables:

$$
\begin{aligned}
& \gamma=\left\{\gamma_{1}, \gamma_{2}, \gamma_{3} \ldots \ldots \gamma_{n}\right\} \\
& \beta=\left\{\beta_{1}, \beta_{2}, \beta_{3} \ldots \ldots \beta_{m}\right\}
\end{aligned}
$$

Where, $\gamma_{1}, \gamma_{2}, \gamma_{3} \ldots \ldots \gamma_{n}$ are the assessed environmental parameters $(\mathrm{n}$ is chosen as 8) and $\beta_{1}, \beta_{2}, \beta_{3} \ldots \ldots \beta_{m}$ are the chosen limits for the respective parameters. The criteria limit for this study are based on USEPA standard on the utilization of sludge and manure for land application [20, 40]. Provided the pathogen densities and vector attraction reduction limits have been met, this regulation affirmed two major scenarios under which an organic material can be applied to agricultural land and forest. The first scenario highlights the organic materials that can be land applied with little or no management practices and site restrictions, the concentrations of all the regulated heavy metals in such fertilizers must meet the pristine class concentration limits. Contrarily, scenario two discusses the organic fertilizers that must be land applied only if the cumulative pollutant loading rate is to be maintained.

Table-2. Regulatory standard limits used in establishing the membership function.

\begin{tabular}{c|c|c|c}
\hline \multirow{2}{*}{ Parameters } & \multicolumn{3}{|c}{ Classifications (mg/kg) } \\
\cline { 2 - 4 } & Pristine $\left[\mathbf{0}, \beta_{1}\right]$ & $\begin{array}{c}\text { Moderately enriched } \\
{\left[\beta_{1}, \beta_{2}\right]}\end{array}$ & $\begin{array}{c}\text { Extremely impacted } \\
{\left[\beta_{2}, \infty\right]}\end{array}$ \\
\hline $\mathrm{As}$ & {$[0,41]$} & {$[41,75]$} & {$[75, \infty]$} \\
\hline $\mathrm{Cd}$ & {$[0,39]$} & {$[39,85]$} & {$[85, \infty]$} \\
\hline $\mathrm{Se}$ & {$[0,36]$} & {$[36,100]$} & {$[100, \infty]$} \\
\hline $\mathrm{Pb}$ & {$[0,300]$} & {$[300,840]$} & {$[840, \infty]$} \\
\hline $\mathrm{Ni}$ & {$\left[0,210^{\dagger}\right]$} & {$\left[210^{\dagger}, 420\right]$} & {$[3000, \infty]$} \\
\hline $\mathrm{Cr} *$ & {$[0,1200]$} & {$[1200,3000]$} & {$[4300, \infty]$} \\
\hline $\mathrm{Cu}$ & {$[0,1500]$} & {$[1500,4300]$} & {$[7500, \infty]$} \\
\hline $\mathrm{Zn}$ & {$[0,2800]$} & {$[2800,7500]$} & \\
\hline
\end{tabular}

Note: * According to Bastian [40] this represents the heavy metal whose limit is under varying degrees of revision. ${ }^{\dagger}$ This limit corresponds to the standard set by Washington State, USA. 
The concentration of one or more toxic pollutants, in such fertilizers, exceeds the pristine quality class but meets the moderately enriched class standard, usually known as the ceiling concentration limit. Organic materials having membership degree in the extremely impacted class is highly detrimental to the environment [41].

\section{Step 2: Establishment of Fuzzy Membership Matrix}

This involves the determination of the degree of membership of an assessed parameter relative to the chosen regulatory criteria limits for each organic fertilizer; these values are then subsequently aggregated and arranged into a fuzzy matrix that can be evaluated with fuzzy reasoning technique. This variable can be defined using Equation 6:

$$
\lambda_{k}=\left[\begin{array}{cccc}
M_{11} & M_{12} & \ldots & M_{1 n} \\
M_{21} & M_{22} & \ldots & M_{2 n} \\
\vdots & \vdots & \ddots & \vdots \\
M_{m 1} & M_{m 2} & \ldots & M_{m n}
\end{array}\right]
$$

Where $\lambda_{K}$ is the membership matrix for each organic fertilizer, $\mathrm{k}$ is the number of assessed fertilizer (that ranged from 1 to 7 ) and $M_{i j}$ is the membership function of the ith parameter relative to the jth criteria limit. As depicted in Figure 1, the trapezoidal membership function was used in defining how the points on the input space are mapped to the corresponding degree of membership function (which ranges from 0 to 1 ); leading to the formulation of Equations $7-9$. From the equations, $\beta_{a}$ and $\beta_{b}$ correspond to the upper limit of $\beta_{1}$ and lower limit of $\beta_{2}$ respectively. The introduction of these limits is as a result of the need to clearly define the fuzzy boundary near the regulatory limits, as well as to fully characterize the trapezoidal membership functions. The fuzzy boundary is considered as the region in which the pollution class changes due to a small variation in the measured data [39]. The lower limit of $\beta_{1}$ and upper limit of $\beta_{2}$ were not considered because they clearly correspond to pristine and extremely impacted class respectively. Based on experts opinion, $\beta_{a}$ and $\beta_{b}$ were determined by placing a bound on $\beta_{1}$ and $\beta_{2}$, see Equations 10 and 11 , to reflect the potential systemic error that can result in bias and subsequently changes the impact class. This bound thus creates a divide between the set of input elements with membership function of one and those that are less than one. For example, for the moderately enriched class, subject to the adopted possible error margin, any data which falls within the interval $\beta_{a} \leq x \leq \beta_{b}$, with certainty, has a membership function of one, and less than one if such data falls within the intervals $\beta_{1}<x<\beta_{a}$ and $\beta_{b}<x<\beta_{2}$ respectively (see Figure 1). To capture the accuracy of the assessment technique, an error (systemic) margin (e) of 5\% was considered [35]. 


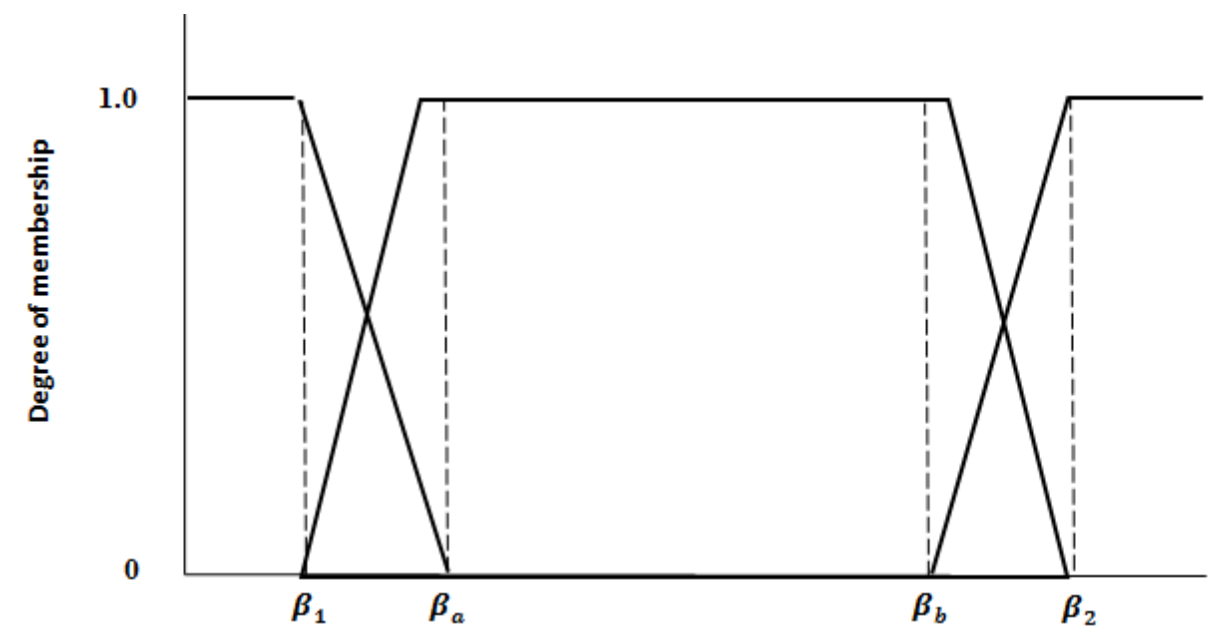

Figure-1. Formulation of fuzzy membership function.

$$
\begin{aligned}
& M_{i, 1}=\left\{\begin{aligned}
1 & \text { when } x \leq \beta_{1} \\
\frac{\beta_{a}-x}{\beta_{a}-\beta_{1}} & \text { when } \beta_{1}<x<\beta_{a} \\
0 & \text { when } x \geq \beta_{a}
\end{aligned}\right\} \\
& M_{i, 2}=\left\{\begin{array}{cc}
0 & \text { when } x \leq \beta_{1} \text { or } \geq \beta_{2} \\
\frac{x-\beta_{1}}{\beta_{a}-\beta_{1}} & \text { when } \beta_{1}<x<\beta_{a} \\
1 & \text { when } \beta_{a} \leq x \leq \beta_{b} \\
\frac{\beta_{2}-x}{\beta_{2}-\beta_{b}} & \text { when } \beta_{b}<x<\beta_{2}
\end{array}\right\} \\
& M_{i, a}=\left\{\begin{aligned}
0 & \text { when } x \leq \beta_{b} \\
x-\beta_{b} & \text { when } \beta_{b}<x<\beta_{2} \\
\beta_{2}-\beta_{b} & \text { when } x \geq \beta_{2}
\end{aligned}\right\}
\end{aligned}
$$

Where $\mathrm{x}\left(\right.$ or $\left.x_{i k}\right)$ is the data obtained from chemical assessment for parameter i under organic fertilizer k.

$$
\begin{aligned}
& \beta_{a}=\beta_{1}+e\left(\beta_{2}-\beta_{1}\right) \\
& \beta_{b}=\beta_{2}-e\left(\beta_{2}-\beta_{1}\right)
\end{aligned}
$$

Step 3: Establishment of fuzzy algorithm

This is the product of the fuzzy membership matrix and an established weight matrix. The weight matrix is obtained by assigning weight to each parameter of interest based on its relative contribution to the level of heavy metal contamination. The fuzzy algorithm is expressed by Equations $12-15$ :

$$
\begin{aligned}
\lambda_{K} W & =\left[\begin{array}{c}
F_{1} \\
F_{2} \\
\vdots \\
F_{j}
\end{array}\right] \\
W & =\left\{w_{1}, w_{2}, \ldots \ldots w_{n}\right\}
\end{aligned}
$$

$$
\sum_{i=1}^{n} w_{i}=1
$$

$$
F_{H}=\max \left\{F_{j}\right\}
$$


Where: $\left\{F_{1}, F_{2}, \ldots \ldots F_{j}\right\}$ is the fuzzy algorithm, W is the weight matrix, w is the weight allocated to each parameter and $F_{H}$ is the maximum impact classification that denotes the degree of contamination.

Weight determination is an important aspect of FCA, as it has a direct influence on the final result [42]. Presently, weight allocation is achieved through the use of approaches such as the analytical hierarchy processes that are highly subjective and complicated when dealing with a large number of evaluation factors [43]. However, the adoption of the entropy weight method, in connection with FCA, has been shown to enhance objectivity, reflect the real situation relevant to the evaluation factors and improve the technicality of the evaluation result [43, 44]. The weight matrix was therefore obtained through the use of the entropy weight method; and according to Salami, et al. [45] Equations $16-19$ are required:

$$
w_{i}=\frac{1-E_{i}}{\sum_{i}^{n}\left(1-E_{i}\right)}
$$

Where $w_{i}$ and $E_{i}$ is the weight and entropy of parameter i respectively.

The entropy can be determined using Equation 16

$$
E_{\mathrm{i}}=-\frac{\sum_{\mathrm{k}}^{g} H_{\mathrm{ik}} \ln H_{\mathrm{ik}}}{\ln s}
$$

Where $H_{i k}$ is the proportion of ith parameter under the kth organic fertilizer (also referred to as standardization), when $H_{\mathrm{ik}}=0$, then $H_{\mathrm{ik}} \ln H_{\mathrm{ik}}=0[43]$.

Similarly, $H_{\text {ik }}$ can be calculated using:

$$
H_{i k}=\frac{x_{i k}}{\sum_{k=1}^{g} x_{i k}}
$$

Where $x_{i k}$ is the value of the ith parameter under the kth organic fertilizer, usually depicted by the original matrix (X), as shown in Equation 19.

$$
X=\left[\begin{array}{cccc}
x_{11} & x_{12} & \ldots & x_{1 n} \\
x_{21} & x_{22} & \ldots & x_{2 n} \\
\vdots & \vdots & \ddots & \vdots \\
x_{g 1} & x_{m 2} & \ldots & x_{n g}
\end{array}\right]
$$

Furthermore, when the measured parameters $\left(x_{i k}\right)$ have excessive zero values, Zhu, et al. [46] opined that the standardized process, Equation 18, is prone to distortion, leading to the assignment of high weight index to these sets of parameters with the least dispersion degree of measured data. The authors further asserted that this anomaly can be corrected using Equations $20-21$. 


$$
H_{i k}=\frac{\left(x_{i k}+C\right)}{\sum_{k=1}^{g}\left(x_{i k}+C\right)}
$$

$$
x_{i k}+C>0
$$

Where $\mathrm{C}$ is the correction factor that must at least satisfy Equation 21. In this study, $\mathrm{C}$ is chosen as the mean of all non-zero data corresponding to the measured parameters with the least degree of dispersion.

\section{RESULT AND DISCUSSION}

\subsection{Chemical Composition of Organic Fertilizers}

The nutrient level in organic fertilizers is a critical factor that governs the development of a comprehensive and effective nutrient management plan, with the sole aim of reducing nutrient runoff to adjacent water bodies while maximizing high crop nutrient utilization [30]. As depicted in Table 3, in the chosen organic fertilizers, the percentage total nitrogen $(\mathrm{TN})$ content decreased in the order of $\mathrm{GNC}>\mathrm{POM}>\mathrm{AWS}>\mathrm{NMC}>\mathrm{SHM}>\mathrm{PCM}>$ CAM while the percentage total phosphate $(\mathrm{TPH})$ decreased in the order of $\mathrm{PCM}>\mathrm{POM}>\mathrm{GNC}>\mathrm{NMC}>\mathrm{SHM}$ $>$ AWS > CAM. In addition, POM has the highest percentage total potash (TPO), followed by GNC and NMC in the second and third positions respectively. However, the lowest percentage TPO was observed in AWS. In comparison with existing data, the percentage TN in SHM and PCM align perfectly with the available data range. A higher percentage TN, beyond the available data range, was nonetheless observed in GNC, POM, and CAM. Furthermore, NMC and AWS possessed a lower percentage of TN when compared with existing data. As noticed in the TN results, similar trends of slight variation from existing data were observed for TPH and TPO of some organic fertilizers. Wide variability in the NPK composition of most organic fertilizers is a common phenomenon, which is as a result of the peculiarity of their respective nutrient source (s) and handling method. For animal-based manure, the variability in the nutrient value particularly depends on several factors such as the amount of bedding materials, size and species of animals, ration feed, degree of moisture, waste management techniques, and the storage methodology [47].

\begin{tabular}{|c|c|c|c|c|c|c|c|}
\hline \multirow{3}{*}{$\begin{array}{c}\text { Organic } \\
\text { fertilizers }\end{array}$} & \multicolumn{6}{|c|}{ Nutrient level (\%) } & \\
\hline & \multicolumn{3}{|c|}{ This study } & \multicolumn{3}{|c|}{ Existing data } & \\
\hline & $\mathbf{T N}$ & ТРН & TPO & $\mathbf{T N}$ & TPH & TPO & Reference \\
\hline CAM & 0.91 & 0.06 & 0.21 & $0.3-0.4$ & $0.1-0.2$ & $0.1-0.3$ & {$[47-50]$} \\
\hline POM & 3.12 & 1.21 & 0.58 & $0.64-2.87$ & $1.4-2.9$ & $0.8-2.35$ & {$[47-50]$} \\
\hline SHM & 1.01 & 0.53 & 0.19 & $0.43-1.55$ & $0.31-0.6$ & $0.03-0.3$ & {$[47-50]$} \\
\hline GNC & 7.44 & 0.87 & 0.41 & $7.0-7.3$ & $1.5-1.65$ & $1.3-1.4$ & {$[47,49]$} \\
\hline NMC & 1.78 & 0.66 & 0.38 & $5.2-5.3$ & $1.0-1.1$ & $1.4-1.5$ & {$[47,49]$} \\
\hline $\mathrm{PCM}$ & 0.97 & 1.61 & 0.34 & $0.4-2.0$ & $0.2-1$ & $0.5-1.5$ & {$[47-49]$} \\
\hline $\mathrm{AWS}^{*}$ & 3.01 & 0.12 & 0.14 & $4.92-4.97$ & $0.3-0.45$ & $0.99-1.26$ & {$[51]$} \\
\hline
\end{tabular}

Table-3. The nutrients contained in selected organic fertilizers.

\subsection{Presence of Heavy Metals in Organic Fertilizers}

The distribution of the average concentrations of eight regulated heavy metals $(\mathrm{Zn}, \mathrm{Cu}, \mathrm{Pb}, \mathrm{Cd}, \mathrm{Cr}, \mathrm{Se}, \mathrm{As}$, and $\mathrm{Ni}$ ) in various organic fertilizers is shown in Table 4. It can be seen from the table that the concentrations of $\mathrm{Cu}$, Se,

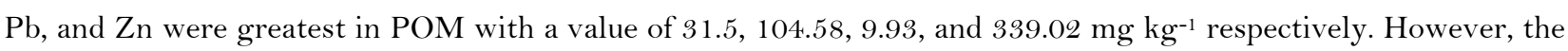
lowest concentrations for $\mathrm{Cu}$ and $\mathrm{Pb}$ were found in AWS with a value of 5.5 and $3.23 \mathrm{mg} \mathrm{kg}^{-1}$ respectively, while the least concentrations of Se $\left(36.98 \mathrm{mg} \mathrm{kg}^{-1}\right)$ and $\mathrm{Zn}\left(32.59 \mathrm{mg} \mathrm{kg} \mathrm{kg}^{-1}\right)$ were observed in GNC. The highest concentrations of $\mathrm{Cd}, \mathrm{Cr}$, and $\mathrm{Ni}$ were observed in $\mathrm{PCM}$ with a value of 1533.89 , 1793.31, and $18.87 \mathrm{mg} \mathrm{kg}^{-1}$ 
respectively while the lowest concentrations of these three metals were found in NMC. On the other hand, the presence of As contamination was found only in SHM and PCM. The low concentration of As in PCM and SHM and its nonexistence in other organic fertilizers implies that As contamination is very minimal. The prevalence of low As concentration in cattle, sheep, and poultry manures has been reported [52]. The highest concentration of heavy metals such as $\mathrm{Cu}, \mathrm{Se}, \mathrm{Pb}$, and $\mathrm{Zn}$ found in POM may be as a result of the daily diets of poultry, which mostly contain metals such as $\mathrm{Zn}$, As, and $\mathrm{Cu}$ for boosting growth and resistance to disease [23]. Some of these heavy metals and other micronutrients are known to be discharged through the excreta, which mostly forms the organic fertilizers since they cannot be fully absorbed by the animals [53]. Generally, the considerable high concentrations of heavy metals in animal-based fertilizers (CAM, POM, and SHM) has been attributed to several other factors, such as type of animal, type of housing, type of ration, bedding materials, feed additives, and waste management practices [23].

The reported high concentrations of heavy metals in animal-based align closely to the data posited from existing studies. The study of Liu, et al. [52] compared the distribution of the average concentrations of heavy metals in the manures of livestock and poultry in China, the authors posited that the measured concentrations of seven out of the eight heavy metals $(\mathrm{Zn}, \mathrm{Cd}, \mathrm{Cu}, \mathrm{As}, \mathrm{Cr}, \mathrm{Ni}$, and $\mathrm{Hg}$ ) were significantly higher than the Chinese agricultural industry and Taiwan province standards for organic fertilizers. Furthermore, several studies have shown that these heavy metals contained in animal waste can subsequently accumulate in soil and become readily available to plant [24]. Food crops like vegetables, tubers, fruits, and nuts cultivated in such contaminated lands can amass toxic heavy metals which then pose a significant threat to human health [23]. As evident from Table 4, a high degree of $\mathrm{Cd}$ and $\mathrm{Cr}$ contamination was observed in AWS; which might be as a result of the livestock feed additives and other possible chemical substances used during animal processing. This observation is consistent with the results of the study carried out by Ubwa, et al. [54] the authors reported moderate to high concentrations of Cd and $\mathrm{Cr}$ contamination in the products and byproduct (blood) of slaughtered livestock at the Wurukum Abattoir in Nigeria.

Furthermore, the high concentration of regulated heavy metals in PCM seems to be closely related to the choice of a raw material mix, method of preparation, and operating conditions. The correlation between raw material mix and a high degree of heavy metals in organic fertilizers has been affirmed by Liu, et al. [52]. The authors opined that the use of animal manure, such as poultry droppings, as a raw material in composting, has a direct influence on the degree of heavy metals concentrations in the final commercial products (compost). Similarly, achieving high-quality compost through the appropriate monitoring and controlling of operating conditions, such as $\mathrm{pH}$, temperature, aeration rate, $\mathrm{C}: \mathrm{N}$ ratio, and moisture content, have been reported by Qasim, et al. [55]. The concentrations of the unregulated heavy metals in each of the organic fertilizers have similarly been depicted in Table 4. The concentrations of $\mathrm{Al}, \mathrm{Fe}, \mathrm{Mn}, \mathrm{Ba}, \mathrm{Co}, \mathrm{Ag}$, and $\mathrm{V}$ ranged between 595.43 and 2350.73, 17.46 and 3189.05, 19.10 and 381.65, 6.49 and 158.73, $\mathrm{O}$ and 28.69, 0.07 and 0.30, 0 and $5.05 \mathrm{mg} \mathrm{kg}^{-1}$ respectively. Some of these trace metals are micronutrients that are essential for plant growth and development. The highest concentration of $\mathrm{Al}, \mathrm{Fe}, \mathrm{Mn}$, and $\mathrm{Ag}$ was found in PCM; CAM equally possessed the highest concentration of Ba while the highest concentrations of $\mathrm{Co}$ and $\mathrm{V}$ were notable in POM. The descriptive statistics for the average, maximum, and minimum concentration of heavy metals in the respective organic fertilizer is presented in Table A.1.

\subsection{Cumulative Impact}

The result of the fuzzy membership function, for all the regulated heavy metals, is presented in Figure 2. The metals are arranged in the order of $\mathrm{Cu}, \mathrm{Cd}, \mathrm{Se}, \mathrm{Pb}, \mathrm{Ni}, \mathrm{Cr}, \mathrm{Zn}$, and As. Membership functions that correspond to the pristine, moderately enriched, and extremely impacted classes are arranged in the first, second, and third row respectively for each of the analyzed organic fertilizers. From the figure, the concentrations of $\mathrm{Cu}, \mathrm{Pb}, \mathrm{Ni}, \mathrm{Zn}$, and As fall into the pristine class for all the organic fertilizers. However, in some of the organic fertilizers, the 
concentrations of $\mathrm{Cd}$, Se, and $\mathrm{Cr}$ were observed to be very high relative to the pristine class standards. The presence of these heavy metals in high concentrations is a major source of concerns on food and environmental qualities.

Table-4. Mean concentrations of heavy metals in the studied organic fertilizers.

\begin{tabular}{|c|c|c|c|c|c|c|c|c|}
\hline \multirow[t]{2}{*}{ Heavy metals } & \multirow[t]{2}{*}{ Unit } & \multicolumn{7}{|c|}{ Organic fertilizers } \\
\hline & & CAM & POM & SHM & GNC & NMC & PCM & AWS \\
\hline $\mathrm{Cu}$ & $\mathrm{mg} \mathrm{kg-1}$ & 13.34 & 31.15 & 19.69 & 7.43 & 6.88 & 24.67 & 5.55 \\
\hline $\mathrm{Cd}$ & $\mathrm{mg} \mathrm{kg}^{-1}$ & 279.67 & 65.89 & 187.55 & 10.17 & 9.97 & 1533.89 & 551.92 \\
\hline $\mathrm{Se}$ & $\mathrm{mg} \mathrm{kg}^{-1}$ & 58.37 & 104.58 & 56.89 & 36.98 & 42.16 & 84.40 & 44.62 \\
\hline $\mathrm{Pb}$ & $\mathrm{mg} \mathrm{kg}{ }^{-1}$ & 6.63 & 9.93 & 6.15 & 5.13 & 5.85 & 9.56 & 3.23 \\
\hline $\mathrm{Ni}$ & $\mathrm{mg} \mathrm{kg}^{-1}$ & 8.45 & 7.19 & 11.29 & 5.51 & 4.37 & 18.87 & 6.16 \\
\hline $\mathrm{Cr}$ & $\mathrm{mg} \mathrm{kg}^{-1}$ & 388.61 & 101.15 & 277.82 & 23.98 & 20.37 & 1793.31 & 708.60 \\
\hline $\mathrm{Zn}$ & $\mathrm{mg} \mathrm{kg}^{-1}$ & 75.49 & 339.02 & 129.41 & 32.59 & 36.59 & 250.87 & 33.65 \\
\hline As & $\mathrm{mg} \mathrm{kg} \mathrm{kg}^{-1}$ & $\mathrm{O}$ & $\mathrm{O}$ & 0.295 & $\mathrm{O}$ & $\mathrm{O}$ & 0.055 & $\mathrm{O}$ \\
\hline $\mathrm{Al}$ & $\mathrm{mg} \mathrm{kg}^{-1}$ & 1106.31 & 1095.85 & 1146.72 & 595.43 & 673.70 & 2350.73 & 836.75 \\
\hline $\mathrm{Fe}$ & $\mathrm{mg} \mathrm{kg}^{-1}$ & 671.44 & 125.45 & 466.40 & 20.92 & 17.46 & 3189.05 & 1216.49 \\
\hline $\mathrm{Mn}$ & $\mathrm{mg} \mathrm{kg}^{-1}$ & 244.58 & 257.83 & 267.71 & 32.65 & 16.37 & 381.65 & 19.10 \\
\hline $\mathrm{Ba}$ & $\mathrm{mg} \mathrm{kg-1}$ & 158.73 & 34.03 & 122.09 & 6.49 & 18.13 & 77.08 & 10.65 \\
\hline $\mathrm{Co}$ & $\mathrm{mg} \mathrm{kg}{ }^{-1}$ & 9.69 & 28.69 & 14.56 & 11.40 & 8.85 & $\mathrm{O}$ & 1.27 \\
\hline $\mathrm{Ag}$ & $\mathrm{mg} \mathrm{kg}^{-1}$ & 0.13 & 0.07 & 0.13 & 0.21 & 0.2 & 0.30 & 0.14 \\
\hline $\mathrm{V}$ & $\mathrm{mg} \mathrm{kg}^{-1}$ & 1.42 & 5.05 & 0.71 & 0.77 & 0.38 & 4.59 & $\mathrm{O}$ \\
\hline
\end{tabular}

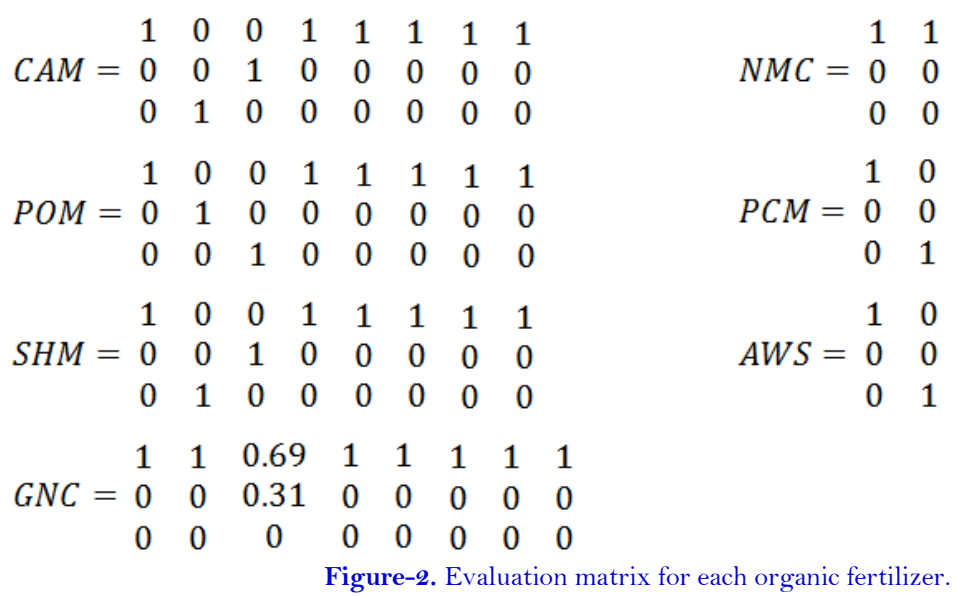

In all the considered organic fertilizers, Se has a membership function of about 9.9, 75.8, and $14.3 \%$ in the pristine, moderately enriched, and extremely impacted class respectively. Moderate level of Se contamination was found in CAM, SHM, NMC, AWC, and PCM with values that exceeded the pristine class standard by 62.14, 58.03, $17.11,134.44$, and $23.94 \%$ respectively. Though Se concentration in GNC exceeded the pristine class standard by $2.72 \%$, it however has a membership degree of approximately $69 \%$ in the pristine class and about $31 \%$ membership function in the moderately enriched class. POM is the only organic fertilizer with an extreme level of Se concentration which exceeded the extremely impacted class standard by approximately 5\%. The presence of Se in plant-based organic fertilizers, beyond the pristine class standard, is an indication of the possibility of its bioaccumulation in plants usually as a result of land contamination. In animal-based fertilizers, the excessive level of trace metals has been strongly associated with chemical additives in animal feeds; which are needed for balanced nutrition and prevention of diseases. A moderate level of Se contamination in PCM is expected, as it contains a sizeable amount of plant and animal-based materials; the extreme concentration of Se in Organic fertilizers is however detrimental to food safety and quality, as it portends a potential pathway for its bioaccumulation in plants and subsequent bio-magnification in humans through the food chain.

Similarly, For Cd contamination, approximately $28.6 \%$ of the organic fertilizers have a membership function in the pristine class, and about 14.3 and $57.1 \%$ membership degree in the moderately enriched and extremely impacted 
class respectively. The Cd concentrations, in GNC and $\mathrm{NMC}$, fall in the pristine quality while its concentration in POM falls within the moderately enriched class with a value that exceeded the pristine class standard by about $70 \%$. However, evidence of a high level of Cd contamination was found in CAM, SHM, PCM, and AWS. These organic fertilizers have major input from animal sources and their respective $\mathrm{Cd}$ concentrations are well above the USEPA extremely impacted class by approximately 229 to $1705 \%$. Likewise, Cr has a membership degree in pristine quality class for about six out of the seven analyzed organic fertilizers. A moderate level of Cr contamination was however observed in PCM with a concentration that is well above the pristine class standard by more than $30 \%$. This high level of $\mathrm{Cr}$ concentration is strongly related to the inclusion of sawdust from industrial settings in the raw material mix for producing PCM, the use of poultry manure, and no compliance with standard preparation methodology. In industrial settings, sawdust is a byproduct from the processing of wood that has been treated with chemical additives such as chromated copper arsenate (CCA) to prevent attacks from insects and microbes. The high risk of leaching of $\mathrm{Cr}, \mathrm{Cu}$, and As from CCA-treated wood and its significant role in environmental degradation has been well documented [56]. The trace level of As concentration in PCM can also be rightly linked to the aforementioned cause. Equally, a high concentration of $\mathrm{Cr}$ in poultry manure and its potential in enriching heavy metal concentration in organic fertilizers has been observed [52].

The presence of excessive concentrations of toxic pollutants such as $\mathrm{Cd}, \mathrm{Zn}$, and $\mathrm{Cr}$ in plants cultivated on contaminated soils, through the application of organic materials, has been documented [18]. This fact corroborated the research output from this study and as it can be observed from Figure 3, $\mathrm{Cd}$ and $\mathrm{Cr}$ accounted for more than $60 \%$ contribution to the level of contaminants in the selected organic fertilizers. $\mathrm{Zn}$ is also a major contributor with a weighted index of approximately $16 \%$, while the other heavy metals have a total weight contribution of about $22 \%$. Cang, et al. [57] equally reported high concentrations of $\mathrm{Cd}, \mathrm{Cr}$, and $\mathrm{Zn}$ in several organic materials of animal origin. Furthermore, as depicted in Figure 3, the fuzzy algorithm result categorized the selected organic fertilizers as pristine (fuzzy index range from 0.35 - 0.99), moderately enriched (fuzzy index range from $0.01-0.33$ ), and extremely impacted (fuzzy index range from o-0.33). Though, the plant-based organic fertilizers, GNC and NMC, with a membership degree of 99 and $97 \%$ respectively, are classified as pristine. These organic fertilizers, due to the presence of contaminants in the moderately enriched class, can however only be land applied if the cumulative pollutant loading rate and other site restrictions are met. Unless adequate remediation techniques and good management practices are put in place, the application of CAM, POM, SHM, PCM, and AWS on agricultural land poses an imminent threat to food security, public health, and the environment. All these aforementioned organic fertilizers have a membership index in the extremely impacted class, ranging from 3 to $33 \%$, which can cause land contamination when used and subsequent negative impacts on plants, humans, and the environment.

$\begin{array}{rrrr}C u=0.08 & 0.64 & 0.99 & 0.64 \\ C d=0.33 & C A M=0.03 & G N C=0.01 & A W S=0.03 \\ S e=0.03 & 0.33 & 0 & 0.33 \\ W b=0.02 & & & \\ N i=0.05 & P O M=0.33 & N M C=0.03 & 0 \\ C r=0.29 & 0.03 & & 0.35 \\ \mathrm{Zn}=0.16 & 0.64 & P C M=0.32 & 0.33\end{array}$

Figure-3. Fuzzy weight matrix and impact classification matrices.

\section{CONCLUSION}

In this study, some of the available organic fertilizers, in Nigeria, have been assayed for nutrient content and heavy metal contamination. These organic fertilizers are suitable soil amendment materials of optimum nutrients 
values but with some level of heavy metal contamination. $\mathrm{Zn}, \mathrm{Cr}$, and $\mathrm{Cd}$ were identified as the major contaminants that accounted for close to $80 \%$ of the total degree of pollution in the analyzed organic fertilizers. Based on the fuzzy algorithm classification, the plant-based organic fertilizers, GNC and NMC, are categorized as suitable soil improvers of pristine quality that can be land applied under strict compliance with pollutant loading rate and other site restrictions. However, CAM, POM, SHM, PCM, and AWS have been identified to possess varying degrees of contamination in the extremely impacted class and as such pose a great danger to the ecosystem. To therefore protect the environment and public health, on the quest towards achieving food security, adequate remediation techniques, and good management practices are to be promoted among the producers and users of these soil improvers in Nigeria. Furthermore, the degree of toxicity in PCM can be greatly reduced if great attention is placed on the choice of raw materials mix and sound method of preparation.

Funding: This study received no specific financial support.

Competing Interests: The authors declare that they have no competing interests.

Acknowledgement: The lead author would like to thank Dr. Foluso Oyedotun Agunbiade for delivering a comprehensive lecture on the scope and application of fuzzy comprehensive assessment.

\section{REFERENCES}

[1] K. Havas and M. Salman, "Food security: Its components and challenges," International Journal of Food Safety, Nutrition and Public Health, vol. 4, pp. 4-11, 2011.Available at: https://doi.org/10.1504/ijfsnph.2011.042571.

[2] FAO, "The state of food security and nutrition in the world: Safeguarding against economic slowdowns and downturns," ed Rome, Italy: Food and Agriculture Organization of the United Nations Rome, 2019, pp. 1-10.

[3] S. Matemilola and I. Elegbede, "The challenges of food security in Nigeria," Open Access Library Journal, vol. 4, pp. 122, 2017.Available at: https://doi.org/10.4236/oalib.1104185.

[4] FAO, Towards zero hunger and sustainability. Food and Agriculture Organization of the United Nations Rome, 2017.

[5] B. Hornick, "Nutritional quality of crops as affected by management practices. Retrieved from http://www.infrc.or.jp/english/KNF_Data_Base_Web/PDF," pp. 1-8, 2005.

[6] J. Visser, Opening history: Gaining perspectives. Organic fertilizers: History, production and applications. London, UK: IntechOpen, 2019.

[7] M. Jallow, A. Dahab, and M. Albaho, Chapter 4: Environmental and human health impacts of pesticide use in Agriculture. Pesticides, Hyderabad 500029, Telangana, India: Avidscience, 2017.

[8] P. Prashar and S. Shah, "Impact of fertilizers and pesticides on soil microflora in agriculture," ed NewYork city, USA: Springer International Publishing, 2016, pp. 331-61.

[9] P. Nicolopoulou-Stamati, S. Maipas, C. Kotampasi, P. Stamatis, and L. Hens, "Chemical pesticides and human health: The urgent need for a new concept in agriculture," Frontiers in Public Health, vol. 4, p. 148, 2016.Available at: https://doi.org/10.3389/fpubh.2016.00148.

[10] B. W. Green, "Fertilizers in aquaculture. In Feed and Feeding Practices in Aquaculture," ed Sawston, United Kingdom: Woodhead Publishing, 2015, pp. 27-52.

[11] Synagra, "History of organic fertilizers. Retrieved from https://synagragroup.com/article-15-History-of-organicfertilizers.html. [Accessed June 2, 2021]," 2017.

[12] W. Lin, M. Lin, H. Zhou, H. Wu, Z. Li, and W. Lin, "The effects of chemical and organic fertilizer usage on rhizosphere soil in tea orchards," PloS One, vol. 14, p. e0217018, 2019.Available at: https://doi.org/10.1371/journal.pone.0217018.

[13] S. H. Han, J. Y. An, J. Hwang, S. B. Kim, and B. B. Park, "The effects of organic manure and chemical fertilizer on the growth and nutrient concentrations of yellow poplar (Liriodendron tulipifera Lin.) in a nursery system," Forest Science and Technology, vol. 12, pp. 137-143, 2016.Available at: https://doi.org/10.1080/21580103.2015.1135827. 
[14] R. Miller, "Inorganic fertilizer Vs. Organic fertilizer. Retrieved from https://homeguides.sfgate.com/inorganicfertilizer-vs-organic-fertilizer-39528.html. [Accessed August 15, 2021]," pp. 1-25, 2018.

[15] S. P. Kayastha, "Heavy metal pollution of agricultural soils and vegetables of Bhaktapur district, Nepal," Scientific World, vol. 12, pp. 48-55, 2014.Available at: https://doi.org/10.3126/sw.v12i12.13597.

[16] J. Mortvedt, "Heavy metal contaminants in inorganic and organic fertilizers," Fertilizer Research, vol. 43, pp. 55-61, 1995.Available at: https://doi.org/10.1007/bfo0747683.

[17] P. Rai, S. Lee, M. Zhang, Y. Tsang, and K. Kim, "Heavy metals in food crops: Health risks, fate, mechanisms, and management," Environment International, vol. 125, pp. 365-385, 2019.Available at: https://doi.org/https://doi.org/10.1016/j.envint.2019.01.067.

[18] J. Olowoyo and L. Mugivhisa, "Evidence of uptake of different pollutants in plants harvested from soil treated and fertilized with organic materials as source of soil nutrients from developing countries," Chemical and Biological Technologies in Agriculture, vol. 6, pp. 1-11, 2019.Available at: https://doi.org/10.1186/s40538-019-0165-0.

[19] M. Souri, M. Hatamian, and T. Tesfamariam, "Plant growth stage influences heavy metal accumulation in leafy vegetables of garden cress and sweet basil," Chemical and Biological Technologies in Agriculture, vol. 6, pp. 1-7, 2019.Available at: https://doi.org/10.1186/s40538-019-0170-3.

[20] Q. Gong, P. Chen, R. Shi, Y. Gao, S. Zheng, and Y. Xu, "Health assessment of trace metal concentrations in organic fertilizer in Northern China," International Journal of Environmental Research and Public Health, vol. 16, pp. 1-22, 2019.Available at: https://doi.org/10.3390/ijerph16061031.

[21] P. Chauhan, A. Singh, R. Singh, and M. Ibrahim, Environmental impacts of organic fertilizers usage in agriculture. Organic fertilizers: Types, production, and environmental impact. Hauppauge: Nova Science Publisher, 2012.

[22] R. Wiederholt and B. Johnson, "Environmental implications of excess fertilizer and manure on water quality. North Dakota State Univ - NDSU Ext Serv 2017. Retrieved from https://www.ag.ndsu.edu/publications/environmentnatural-resources/environmental-implications-of-excess-fertilizer-and-manure-on-water-quality," 2017.

[23] M. Irshad, A. H. Malik, S. Shaukat, S. Mushtaq, and M. Ashraf, "Characterization of heavy metals in livestock manures," Polish Journal of Environmental Studies, vol. 22, pp. 1257-1262, 2013.

[24] U. Chibueze, O. Dickson, and S. Chinwendu, "Heavy metal contents of inorganic and organic fertilizers commonly used in Southeast Nigeria," Am Open Agriculture, Science, Technology, vol. 1, pp. 1-9, 2013.

[25] F. Agunbiade, A. Awe, and K. Adebowale, "Fuzzy logic-based modeling of the impact of industrial activities on the environmental status of an industrial estate in Nigeria," Toxicology Environmental Chemistry, vol. 93, pp. 1856-1879, 2011.Available at: https://doi.org/10.1080/02772248.2011.623678.

[26] O. Akintola, A. Sangodoyin, and F. Agunbiade, "Fuzzy logic modelling of the effects of pollution on domestic roofharvested rainwater quality in residential and industrial environments," Archives of Environmental Contamination and Toxicology, vol. 71, pp. 113-21, 2016.Available at: https://doi.org/10.1007/s00244-016-0278-4.

[27] P. Olaito, "Organic agriculture in Nigeria," ed Nigeria: Global Agricultural Information Network, 2014, pp. 1-5.

[28] S. Usman and A. Kundiri, "Values of organic materials as fertilizers to Northern Nigerian crop production systems," Journal of Soil Science and Environmental Management, vol. 7, pp. 204-211, 2019.Available at: https://doi.org/10.5897/JSSEM2015.0532.

[29] USEPA, Environmental regulations and technology: Control of pathogens and vector attraction in sewage sludge (EPA/625/R92/O13). Washington, DC: U.S. Environmental Protection Agency Office of Wastewater Management, 2003.

[30] T. Salo, A. Myrbeck, L. Leitans, V. Ribikauskas, I. Subbotin, and S. Luostarinen, "Instructions for manure analysis," ed 18055 Rostock, Germany: Interreg Baltic Sea Region, 2020, pp. 1-32.

[31] M. Motsara and R. Roy, "Guide to laboratory establishment for plant nutrient analysis," ed Rome, Italy: Food and Agricultural Organization of the United Nations, 2008, pp. 42-50.

[32] PanReac, Determination by Kjeldahl method Nitrogen determination by Kjeldahl method (A173_EN). Spain: PanReac Quim SLU, 2017. 
[33] BIS, "PART 3 determination of phosphorus (Section 2 Test Methods Not Covered Under Dual Number Standards), Methods of Sampling and Test for Fertilizers," ed India: Bureau of Indian Standards, 2004, pp. 1-12.

[34] AFA, "Phosphate and potash fertilizer (Sampling and analysis guide)," ed Cairo, Egypt: Arab Fertilizer Association, 2013, pp. 28-31.

[35] V. Balaram, "Microwave plasma atomic emission spectrometry (MP-AES) and its applications - a critical review," Microchemical Journal, vol. 159, p. 105483, 2020.Available at: https://doi.org/10.1016/j.microc.2020.105483.

[36] USEPA, Method 3050B: Acid digestion of sediments, sludges, and soils. Washington, DC: U.S. Environmental Protection Agency Office of Wastewater Management, 1996.

[37] D. Sullivan, C. Cogger, and A. Bary, "Fertilizing with biosolids fertilizing with biosolids (PNW 508)," ed USA: Pacific Northwest Extension Service, 2015, pp. 1-19.

[38] F. O. Agunbiade, B. I. Olu-Owolabi, and K. O. Adebowale, "Fuzzy logic modeling of bioaccumulation pattern of metals in coastal biota of Ondo State, Nigeria," Environmental Monitoring and Assessment, vol. 184, pp. 89-102, 2012.Available at: https://doi.org/10.1007/s10661-011-1949-2.

[39] K. O. Adebowale, F. O. Agunbiade, and B. I. Olu-Owolabi, "Fuzzy comprehensive assessment of metal contamination of water and sediments in Ondo Estuary, Nigeria," Chemistry and Ecology, vol. 24, pp. 269-283, 2008.Available at: https://doi.org/10.1080/02757540802255600.

[40] R. Bastian, Part 1.1 C biosolids regulations. BIOSOLIDS management handbook. U.S. Washington, DC: Environmental Protection Agency Office of Wastewater Management, 1995.

[41] USEPA, A plain English guide to the EPA part 503 biosolids rule (EPA/832/R-93/O03). Washington, DC: U.S. Environmental Protection Agency Office of Wastewater Management, 1994.

[42] H. Zhang, "Application on the Entropy method for determination of weight of evaluating index in fuzzy mathematics for wine quality assessment," Advance Journal of Food Science and Technology, vol. 7, pp. 195-198, 2015.Available at: https://doi.org/10.19026/ajfst.7.1293.

[43] X. Ding, X. Chong, Z. Bao, Y. Xue, and S. Zhang, "Fuzzy comprehensive assessment method based on the entropy weight method and its application in the water environmental safety evaluation of the Heshangshan drinking water source area, three gorges Reservoir Area, China," Water, vol. 9, pp. 1-15, 2017.Available at: https://doi.org/10.3390/w9050329.

[44] X. Zhao, Q. Qi, and R. Li, "The establishment and application of fuzzy comprehensive model with weight-based on entropy technology for air quality assessment," Procedia Engineering, vol. 7, pp. 217-222, 2010.Available at: https://doi.org/10.1016/j.proeng.2010.11.034.

[45] H. Salami, S. Lawal, T. Bademosi, O. Olowosokedile, and H. Olalekan, "A multicriteria decision based assessment of agricultural solid wastes as potential feedstock for electricity generation in Nigeria," Journal of Fundamental and Applied Sciences, vol. 13, pp. 141 1-1446, 2021 .Available at: https://doi.org/http://dx.doi.org/10.4314/jfas.v13i3.18.

[46] Y. Zhu, D. Tian, and F. Yan, "Effectiveness of entropy weight method in decision-making," Mathematical Problems in Engineering, pp. 1-5, 2020.Available at: https://doi.org/https://doi.org/10.1155/2020/3564835.

[47] R. Roy, A. Finck, G. Blair, and H. Tandon, "Sources of plant nutrients and soil amendments. Plant nutrition for food security: A guide for integrated nutrient management," ed Rome, Italy: Food and Agricultural Organization of the United Nations, 2006, pp. 91-140.

[48] U. Waniyo, M. Sauwa, A. Ngala, G. Abubakar, and E. Anelo, "Influence of sources and rates of manure on yield and nutrient uptake of maize ( Zea mays L .) in Maiduguri, Nigeria," Nigerian Journal of Basic and Applied Sciences, vol. 21 , pp. 259-265, 2013.Available at: https://doi.org/http://dx.doi.org/10.4314/njbas.v21i4.3.

[49] J. Verma and R. Verma, "Organic fertilizers : Types, production and environmental impact. Organic fertilizers: Types, production and environmental impact," ed NewYork City, USA: Nova Science Publisher Incorporation, 2012, pp. 217232. 
[50] FAO, "Fertilizer use by crop in Ghana," ed Rome, Italy: Food and Agricultural Organization of the United Nations, 2005, pp. 1-20.

[51] M. Roy, S. Karmakar, A. Debsarcar, P. K. Sen, and J. Mukherjee, "Application of rural slaughterhouse waste as an organic fertilizer for pot cultivation of solanaceous vegetables in India," International Journal of Recycling of Organic Waste in Agriculture, vol. 2, pp. 1-11, 2013.Available at: https://doi.org/10.1186/2251-7715-2-6.

[52] W. Liu, D. Zeng, L. She, W. Su, D. He, and G. Wu, "Science of the total environment comparisons of pollution characteristics, emission situations, and mass loads for heavy metals in the manures of different livestock and poultry in China," Science of the Total Environment, vol. 734, pp. 1-13, 2020.Available at: https://doi.org/10.1016/j.scitotenv.2020.139023.

[53] J. Jensen, N. C. Kyvsgaard, A. Battisti, and K. E. Baptiste, "Environmental and public health related risk of veterinary zinc in pig production-using Denmark as an example," Environment International, vol. 114, pp. 181-190, 2018.Available at: https://doi.org/10.1016/j.envint.2018.02.007.

[54] S. Ubwa, R. Ejiga, P. Okoye, and Q. Amua, "Assessment of heavy metals in the blood and some selected entrails of cows, goat, and pigs slaughtered at wurukum abattoir, Makurdi-Nigeria," Advances in Analytical Chemistry, vol. 7, pp. 712, 2017.Available at: https://doi.org/10.5923/j.aac.20170701.02.

[55] W. Qasim, M. Lee, B. Eun, F. Okyere, F. Khan, and M. Nafees, "Composting of chicken manure with a mixture of sawdust and wood shavings under forced aeration in a closed reactor system," International Journal of Recycling of Organic Waste in Agriculture, vol. 7, pp. 261-7, 2018.Available at: https://doi.org/10.1007/s40093-018-02 12-z.

[56] A. Moghaddam and C. Mulligan, "Leaching of heavy metals from chromated copper arsenate ( CCA ) treated wood after disposal," Waste Manag, vol. 28, pp. 628-637, 2008.Available at: https://doi.org/10.1016/j.wasman.2007.03.009.

[57] L. Cang, Y.-j. Wang, D.-m. Zhou, and Y.-h. Dong, "Heavy metals pollution in poultry and livestock feeds and manures under intensive farming in Jiangsu Province, China," Journal of Environmental Sciences, vol. 16, pp. 371-374, 2004. 


\section{APPENDIX}

Table-A.1. Descriptive statistics for heavy metals concentration in selected organic fertilizers

\begin{tabular}{|c|c|c|c|c|c|c|c|c|}
\hline \multicolumn{2}{|c|}{ Heavy metals } & \multicolumn{7}{|c|}{ Organic fertilizers } \\
\hline & & CAM & POM & SHM & GNC & NMC & PCM & AWS \\
\hline \multirow[t]{3}{*}{$\mathrm{Cu}$} & Max & 13.57 & 31.43 & 19.82 & 7.50 & 7.05 & 24.81 & 5.65 \\
\hline & Mean & 13.34 & 31.15 & 19.69 & 7.43 & 6.88 & 24.67 & 5.55 \\
\hline & Min & 13.10 & 30.86 & 19.56 & 7.35 & 6.71 & 24.52 & 5.44 \\
\hline \multirow[t]{3}{*}{ Cd } & Max & 283.86 & 67.20 & 189.70 & 11.19 & 12.39 & 1544.01 & 557.49 \\
\hline & Mean & 279.67 & 65.89 & 187.55 & 10.17 & 9.97 & 1533.89 & 551.92 \\
\hline & Min & 275.47 & 64.58 & 185.39 & 9.15 & 7.55 & 1523.77 & 546.34 \\
\hline \multirow[t]{3}{*}{ Se } & Max & 64.89 & 110.47 & 78.04 & 63.42 & 49.57 & 90.20 & 58.12 \\
\hline & Mean & 58.37 & 104.58 & 56.89 & 36.98 & 42.16 & 84.40 & 44.62 \\
\hline & Min & 51.85 & 98.69 & 35.74 & 10.54 & 34.74 & 78.59 & 31.11 \\
\hline \multirow[t]{3}{*}{$\mathrm{Pb}$} & Max & 7.71 & 11.45 & 6.55 & 6.25 & 6.76 & 11.17 & 4.07 \\
\hline & Mean & 6.63 & 9.93 & 6.15 & 5.13 & 5.85 & 9.56 & 3.23 \\
\hline & Min & 5.54 & 8.41 & 5.74 & 4.00 & 4.93 & 7.94 & 2.39 \\
\hline \multirow[t]{3}{*}{$\mathrm{Ni}$} & Max & 9.14 & 8.34 & 12.53 & 7.20 & 6.75 & 20.08 & 7.84 \\
\hline & Mean & 8.45 & 7.19 & 11.29 & 5.51 & 4.37 & 18.87 & 6.16 \\
\hline & Min & 7.76 & 6.03 & 10.04 & 3.81 & 1.99 & 17.66 & 4.48 \\
\hline \multirow[t]{3}{*}{$\mathrm{Cr}$} & Max & 391.33 & 101.71 & 279.51 & 24.29 & 20.59 & 1805.15 & 709.94 \\
\hline & Mean & 388.61 & 101.15 & 277.82 & 23.98 & 20.37 & 1793.31 & 708.60 \\
\hline & Min & 385.89 & 100.59 & 276.12 & 23.67 & 20.14 & 1781.47 & 707.25 \\
\hline \multirow[t]{3}{*}{$\mathrm{Zn}$} & Max & 78.49 & 341.76 & 130.80 & 34.51 & 39.10 & 257.89 & 35.29 \\
\hline & Mean & 75.49 & 339.02 & 129.41 & 32.59 & 36.59 & 250.87 & 33.65 \\
\hline & Min & 72.49 & 336.27 & 128.01 & 30.67 & 34.08 & 243.84 & 32.01 \\
\hline \multirow[t]{3}{*}{ As } & Max & 0.00 & 0.00 & 0.58 & 0.00 & 0.00 & 0.11 & 0.00 \\
\hline & Mean & 0.00 & 0.00 & 0.295 & 0.00 & 0.00 & 0.06 & 0.00 \\
\hline & Min & 0.00 & 0.00 & 0.01 & 0.00 & 0.00 & $\mathrm{O}$ & 0.00 \\
\hline \multirow[t]{3}{*}{ Al } & Max & 1113.50 & 1110.64 & 1152.22 & 599.00 & 678.07 & 2364.60 & 845.03 \\
\hline & Mean & 1106.31 & 1095.85 & 1146.72 & 595.43 & 673.70 & 2350.73 & 836.75 \\
\hline & Min & 1099.12 & 1081.06 & 1141.21 & 591.86 & 669.32 & 2336.86 & 828.47 \\
\hline \multirow[t]{3}{*}{$\mathrm{Fe}$} & Max & 677.15 & 126.37 & 470.55 & 21.70 & 17.85 & 3229.23 & 1219.16 \\
\hline & Mean & 671.44 & 125.45 & 466.40 & 20.92 & 17.46 & 3189.05 & 1216.49 \\
\hline & Min & 665.73 & 124.53 & 462.25 & 20.14 & 17.06 & 3148.86 & 1213.81 \\
\hline \multirow[t]{3}{*}{ Mn } & $\operatorname{Max}$ & 249.98 & 263.32 & 270.84 & 33.69 & 16.75 & 388.41 & 19.29 \\
\hline & Mean & 244.58 & 257.83 & 267.71 & 32.65 & 16.37 & 381.65 & 19.10 \\
\hline & Min & 239.17 & 252.34 & 264.57 & 31.61 & 15.98 & 374.89 & 18.90 \\
\hline \multirow[t]{3}{*}{$\mathbf{B a}$} & Max & 160.46 & 34.25 & 122.66 & 6.55 & 18.18 & 77.60 & 10.79 \\
\hline & Mean & 158.73 & 34.03 & 122.09 & 6.49 & 18.13 & 77.08 & 10.65 \\
\hline & Min & 156.99 & 33.81 & 121.52 & 6.43 & 18.07 & 76.56 & 10.51 \\
\hline \multirow[t]{3}{*}{ Co } & Max & 12.08 & 32.76 & 17.02 & 14.50 & 9.60 & 0.00 & 1.57 \\
\hline & Mean & 9.69 & 28.69 & 14.56 & 11.40 & 8.85 & 0.00 & 1.27 \\
\hline & Min & 7.30 & 24.62 & 12.10 & 8.29 & 8.09 & 0.00 & 0.96 \\
\hline \multirow[t]{3}{*}{$\mathrm{Ag}$} & Max & 0.15 & 0.13 & 0.16 & 0.27 & 0.26 & 0.36 & 0.22 \\
\hline & Mean & 0.13 & 0.07 & 0.13 & 0.21 & 0.20 & 0.30 & 0.14 \\
\hline & Min & 0.10 & 0.00 & 0.10 & 0.14 & 0.14 & 0.23 & 0.06 \\
\hline \multirow[t]{3}{*}{ V } & Max & 2.03 & 5.66 & 0.93 & 1.11 & 0.73 & 4.81 & 0.00 \\
\hline & Mean & 1.42 & 5.05 & 0.71 & 0.77 & 0.38 & 4.59 & 0.00 \\
\hline & Min & 0.81 & 4.44 & 0.49 & 0.42 & 0.03 & 4.36 & 0.00 \\
\hline
\end{tabular}

Views and opinions expressed in this article are the views and opinions of the author(s), Current Research in Agricultural Sciences shall not be responsible or answerable for any loss, damage or liability etc. caused in relation to/arising out of the use of the content. 